\title{
ANALISIS PERUBAHAN SIFAT KARAKTER DI SEPANJANG PERJALANANNYA BERDASARKAN POLA KEJADIAN DAN PLOT SEGMENT DALAM FILM "GREEN BOOK"
}

\author{
William Sanjaya \\ Mahasiswa Penciptaan Seni Videografi \\ Program Pascasarjana Institut Seni Indonesia Yogyakarta \\ Jalan Suryodiningratan No. 8, Mantirejon, Yogyakarta \\ No Hp:+6281216197879, E-mail:williamsanjaya1993@gmail.com
}

\begin{abstract}
ABSTRAK
Film "Green Book" merupakan film yang membahas diskriminasi yang dialami oleh pekerja Itali bersama teman sekaligus atasannya yang merupakan orang Negro. Pola kejadian dalam keseluruhan cerita dapat dilihat melalui rangkaian adegan yang menggambarkan perjalanan karakter. Dalam pola kejadian tersebut, perubahan sifat karakter dapat dilihat melalui setiap masalah dari luar (outer problem) dan masalah batin (inner problem) yang dialami. Perubahan tersebut memberikan nilainilai yang merefleksikan kehidupan. Penelitian ini bertujuan untuk mengetahui pola kejadian dan perubahan karakter di sepanjang perjalanan karakter dalam cerita. Metode yang digunakan dalam penelitian ini adalah kualitatif deskriptif yang mengumpulkan berbagai macam teori sebagai bahan untuk menganalisis secara akurat. Teori yang digunakan adalah teori plot segment dari David Bordwell, 7 pola kejadian dalam cerita oleh David Trottier, dan perubahan sifat karakter sepanjang perjalanan oleh Christopher Vogler. Dari penjabaran yang telah dilakukan, disimpulkan bahwa terdapat 7 pola kejadian yang dapat digambarkan melalui setiap kejadian dalam cerita film. Perubahan sifat karakter terjadi sepanjang perjalanan yang dihadapi. Perubahan karakter tersebut memberi nilai yang merefleksikan nilai-nilai kehidupan.
\end{abstract}

Kata kunci: pola kejadian, sifat karkater, segmentasi plot

\begin{abstract}
Analysis of Changes in Character's Trait Based on Event Patterns and Plot Segmentation in the Film "Green Book". The film "Green Book" is a film that discusses the weakening perfection of Italian workers and their Negro friends. The pattern of events in the whole story can be seen through a series of scenes that depict the character's journey. In the pattern of events, changes in character traits can be seen through every problem from the outside (external problems) and inner problems (inner problems) that can be seen. These changes provide values that reflect life. This study aims to look at patterns of events and character changes along the character's journey. The method used in this research is descriptive qualitative which collects various theories as material to analyze accurately. The theory used is the plot segment theory by David Bordwell, 7 patterns of events in the story by David Trottier and changes in character traits along the way by Christopher Vogler. From the description that has been done, it is revealed that there are 7 patterns of events that can be described through each incident in the film story. Changes in character traits occur along the way. The change in character gives values that reflect the values of life.
\end{abstract}

Keywords: pattern of events, character trait, plot segmentation 


\section{PENDAHULUAN}

Film dengan genre drama comedy merupakan film dengan cerita drama yang memberikan beberapa adegan-adegan lucu di dalamnya. Walaupun dibawakan dengan cara serius, film drama komedi tetap membuat penonton tertawa dengan tingkah laku dari peran- peran yang ada dalam cerita film tersebut (Bordwell \& Thompson, 2019). Selain genre comedy, film "Green Book" juga merupakan film yang bergenre buddy love. Genre buddy merupakan genre yang menggambarkan perjalanan bersama antara dua karakter yang saling membutuhkan (Snyder, 2005).

Film "Green Book" merupakan film tentang seorang pekerja berwatak keras dengan ras Itali, Tony Lip yang menemani perjalanan konser dengan seorang Negro yang bernama Dr. Don Shirley. Di sepanjang perjalanan mereka, Tony Lip harus menggunakan buku paduan tentang tempattempat hunian untuk orang Negro yang disebut Green Book. Film "Green Book" mengangkat tentang kisah orang African American yang mengalami diskriminasi keras terhadap orangorang kulit putih pada tahun 1962. Don Shirley merupakan salah satu promotor penggerak orang kulit hitam sebagai dokter dalam bidang literasi dan psikologi yang terkenal dengan kemampuan bermain pianonya pada masa itu (Farrelly, 2019).

Karakter merupakan penggerak cerita dalam sebuah film. Perjalanan karakter dapat dilihat melalui setiap adegan dan situasi yang dialami oleh karakter dalam setiap kejadian dalam sebuah film (Egri, 1946). Cerita merupakan susunan kejadian yang terjadi secara kronologis, tetapi terkadang filmmaker menyampaikan cerita tersebut dengan menampilkan flashback secara tidak urut. Cara penyampaian cerita tersebut yang disebut dengan plot (Bordwell \& Thompson, 2019). Film "Green Book" memiliki beberapa plot segment yang dapat dilihat dari sequence dalam tiap-tiap adegannya.

Penelitian yang dilakukan oleh Ratih Juwita Sari (2020) menganalisis tentang perubahan peran karakter utama untuk membangun tahapan tangga dramatik dalam sebuah film. Penelitian tersebut menekankan pada perubahan karakter yang mendukung tangga dramatik dalam sebuah cerita, sedangkan penelitian ini berfokus pada perjalanan karakter yang dilihat dari segmentasi plot melalui rangkaian adegan atau sequence serta perubahan sifat melalui masalah luar (outer problem) dan masalah batin (inner problem) pada karakter. Melalui perjalanannya, karakter mendapatkan masalah yang mengubah sifat karakter, perubahan tersebut juga merefleksikan nilai-nilai kehidupan (Sari, 2020).

David Trottier (2010) menjelaskan bahwa setiap cerita dalam film memiliki 7 pola kejadian yang terdiri dari back story, catalyst, big event, mid point atau pinch, crisis, showdown atau climax, dan realization (Trottier, 2019).

Back story merupakan kejadian yang menceritakan informasi tentang masa lalu karakter. Back story juga dapat menunjukkan kelemahan karakter dalam sebuah adegan. Back story biasanya ditampilkan pada awal adegan dalam sebuah cerita film. Namun, terkadang ada beberapa cerita yang tidak memiliki back story (Trottier, 2019).

Sementara itu, catalyst merupakan kejadian ketika karakter mulai mengalami dorongan berupa keinginan, kebutuhan, masalah, tujuan, dan misi untuk melakukan sesuatu. Catalyst juga merupakan kejadian ketika karakter mulai melakukan berbagai macam cara untuk mencari jalan keluar dalam masalahnya, tetapi seringkali karakter tidak menemukan jalan keluar hingga sesuatu menimpa dirinya dan membawanya ke dalam sebuah perjalanan yang panjang bersama karakter lain. Catalyst biasanya ditampilkan pada menit ke-10 dalam sebuah film (Trottier, 2019).

Setelahkarakterterdorong untukmelakukan perjalanan, di sepanjang perjalanannya, karakter tersebut akan memasuki pola kejadian big event yang mengubah hidupnya dan membawanya masuk ke dunia barunya. Karakter dihadapkan dengan berbagai rintangan berupa tugas atau masalah yang membuatnya mengalami perubahan 
di sepanjang perjalanannya. Big event biasanya terjadi pada menit ke-20 sampai ke-30 dalam sebuah cerita film (Trottier, 2019).

Mid Point atau pinch merupakan kejadian yang terjadi di pertengahan cerita film. Kejadian tersebut ditandai dengan masuknya karakter ke dalam sebuah perjalanan yang tidak memungkinkan karakter untuk kembali ke dunia awalnya sehingga karakter harus sepenuhnya komitmen untuk menjalani perjalanannya. Dalam tahap ini, karakter akan memiliki motivasi penuh untuk menyelesaikan perjalanan dan menghadapi berbagai rintangan yang ada (Trottier, 2019).

Dalam perjalanan karakter menuju tahap akhir dalam sebuah cerita, karakterakan mengalami berbagai macam masalah yang membuatnya tertekan. Berbeda dengan masalah-masalah yang sebelumnya, masalah yang dialami pada tahap crisis akan membuat karakter belajar tentang sebuah nilai kehidupan yang mengubah hidupnya. Nilai kehidupan tersebut seringkali merefleksikan nilai-nilai sosial yang dapat diterapkan oleh penonton. Namun, di sisi lain karakter juga harus mengambil keputusan penting yang memengaruhi hidupnya sepanjang perjalanan. Crisis biasanya muncul pada akhir sebuah cerita film. Karakter yang melewati pola kejadian crisis akan masuk ke pola kejadian showdown atau climax (Trottier, 2019).

Seperti struktur tiga babak pada umumnya, climax atau showdown merupakan kejadian ketika karakter harus menghadapi musuh atau rintangan terbesarnya. Nasib karakter bergantung pada keputusan yang diambil. Dalam tahap ini, keberhasilan atau kegagalan karakter dalam mencapai tujuannya diperlihatkan sehingga karakter masuk dalam pola kejadian realization (Trottier, 2019).

Pada pola kejadian realization, penonton akan mengetahui bahwa karakter akan mengalami perubahan di sepanjang perjalanan yang karakter alami. Tema dan pesan dalam cerita film ditonjolkan melalui hal-hal yang dipelajari karakter di sepanjang perjalanannya (Trottier, 2019).

Selain itu, karakter juga mengalami perubahan sifat dalam setiap perjalanan yang dihadapinya. Perubahan karakter tersebut dipengaruhi oleh masalah-masalah yang dialami sehingga memberi sebuah nilai yang merefleksikan kehidupan (Vogler, 2007).

Dalam penelitian yang dilakukan Danissa Dyah Oktaviani (2019), dijelaskan bahwa komponen cerita dalam film fantasi dapat dilihat melalui penyusunan ide dan cerita sehingga dapat dilihat oleh penonton. Penelitian tersebut membahas komponen-komponen yang mendukung keseluruhan dalam cerita fiktif dengan genre fantasi. Dalam penelitian ini, komponen cerita dijabarkan dalam bentuk plot segment yang menggambarkan kejadian dalam film "Green Book" (Oktaviani, 2019).

Dalam penelitian ini, film "Green Book" akan dijabarkan melalui plot segment dalam setiap kerangka adegan atau sequence yang ada di dalamnya. Lalu ditambahkan dengan pola-pola kejadian yang menceritakan masalah dan situasi yang dialami karakter dalam setiap pola kejadian tersebut. Melalui penjabaran tersebut, perubahan sifat karakter dapat dilihat dari tindakan terhadap situasi yang dialami selama perjalanannya.

\section{METODE PENELITIAN}

Penelitian ini menggunakan metode kualitatif deskriptif dengan menggunakan sumbersumber yang diambil sebagai bahan analisis perubahan karakter di sepanjang perjalanannya dalam film "Green Book". Tahapan deskriptif dilakukan dengan cara menjabarkan plot segment dalam setiap sequence. Penjabaran tersebut dilakukan untuk mengetahui kejadian yang dialami oleh karakter. Melalui penjabaran tersebut, analisis terhadap tindakan karakter dilakukan dengan mendeskripsikan 7 pola kejadian dalam seluruh cerita. Melalui tindakan karakter tersebut, perubahan sifat karakter disimpulkan dengan cara membandingkan sifat pada awal dan akhir cerita. 


\section{PEMBAHASAN}

\section{Plot Segment}

Setiap cerita memiliki bentuk naratif yang berupa kejadian-kejadian yang diceritakan. Dalam kejadian tersebut, terdapat aspek sebab-akibat, tempat, dan waktu yang dapat dijabarkan. Plot segment dalam film "Green Book" dijabarkan sebagai berikut.

1. Pekerjaan Tony Lip di Copa Club

a. Credit Title

b. Copa Club: Pekerjaan Lama Tony Lip sebagai body-guard di Copa Club. Pada malam hari, Copa Club ditutup karena renovasi.

2. Kehidupan Tony Lip Bersama Keluarga:

a. Rumah: Tony Lip menyapa keluarganya. Ia juga menghina dua orang Negro yang memperbaiki keran di rumahnya.

b. Restaurant: Tony Lip mencari uang dan tawaran pekerjaan pada saat menganggur dengan mengikuti kontes makan.

3. Penawaran Pekerjaan Tony Lip Sebagai Personal Assistant:

a. Kantor Dr. Don Shirley: Tony Lip mengikuti interview sebagai sopir.

b. Bar: Tony Lip mendapatkan tawaran pekerjaan kasar dan menolaknya.

c. Toko arloji: Tony Lip menggadaikan jam tangannya sebagai jaminan.

c. Rumah: Tony Lip mendapatkan pekerjaan.

4. Perjalanan Awal Tony Lip dan Dr. Don Shirley:

a. Depan Kantor Dr. Don Shirley: Tony mempersiapkan perjalanan bersama Dr. Shirley.

b. Dalam perjalanan, Dr. Shirley menjelaskan aturan-aturan selama perjalanannya.

c. Pittsburgh, Pennysylvania: Dr. Shirley memberi aturan tentang cara bersikap saat menjalani konser.

d. Ohio: Tony memberi kabar keluarganya. Di sisi lain, Dr. Shirley menegurnya karena mencuri batu giok.
5. Tony Lip Mempersiapkan Konser Awal Dr. Shirley:

a. Hanover, Indiana: Tony Lip menuntut piano bermerek Steinway kesukaan Dr. Shirley.

b. Chedar Rapids, Iowa: Tony Lip menulis surat untuk keluarganya.

6. Penolakan Dr. Shirley di Beberapa Kota:

a. Louisville, Kentucky: Tony Lip menawarkan Kentucky Fried Chicken. Setelah itu, ia menolong Dr. Shirley di sebuah bar. Keesokan harinya, Dr. Shirley melihat refleksi kehidupan dari petani Negro dalam perjalanannya.

b. Raleigh, North Carolina: Dr. Shirley menolak untuk buang air kecil di toilet khusus orang Negro. Keesokan harinya, Dr. Shirley mengajari Tony Lip menulis surat.

c. Macon, Georgia: Dr. Shirley mengalami diskriminasi dari penjaga toko pakaian. Malam harinya, Tony Lip memberi uang suap pada polisi untuk membebaskan Dr. Shirley.

d. Memphis, Tennessee: Tony Lip menolak tawaran dari teman lamanya. Malam harinya, Dr. Shirley menceritakan studi dan pengalaman bekerja sebagai musisi Negro.

7. Kedekatan Tony Lip dan Dr. Shirley:

a. Keesokan harinya, Dr. Shirley mengajari Tony Lip menulis surat.

b. Little Rock, Arkansas: Tony Lip bercanda dengan Dr. Shirley.

c. Louisiana: Tony Lip menjalani konser bersama Dr. Shirley.

8. Perlawanan Dr. Shirley Terhadap Rasisme di Konser Terakhirnya:

a. Dalam perjalanannya menuju Birningham, Tony Lip dan Dr. Shirley dipenjara. Setelah itu, Dr. Shirley menjelaskan kehidupannya sebagai orang Negro yang mengalami diskriminasi. Malam harinya, Tony Lip menulis surat untuk keluarganya.

b. Birningham, Alabama: Dr. Shirley mengancam tidak tampil karena tidak diperbolehkan makan di restoran bersama 
orang kulit putih. Tony Lip mencoba untuk meyakinkan penjaga restoran, tetapi Dr. Shirley memilih untuk membatalkan konser terakhirnya.

c. Restaurant: Dr. Shirley bermain piano tanpa merek di sebuah bar orang Negro.

9. Akhir Perjalanan Tony Lip dan Dr. Shirley:

a. Dalam perjalanan ke New York, Polisi membantu memperbaiki mobil Tony Lip.

b. New York: Dr. Shirley mengantar Tony Lip. Saat makan malamnya, Dr. Shirley menghampiri Tony Lip.

Penjabaran segmentasi tersebut menggambarkan kejadian yang dialami karakter Tony Lip bersama Dr. Shirley selama perjalanannya di beberapa kota.

\section{Pola Kejadian}

Pola kejadian dalam film "Green Book" disusun melalui kejadian sepajang cerita. Deskripsi dalam pola tersebut juga menjelaskan sifat-sifat karakter dan perubahannya.

\section{Back Story}

Back story merupakan pola kejadian yang menggambarkan latar belakang dan masalah dari karakter. Dalam film "Green Book" terdapat pada plot segment 1 ketika karakter Tony Lip menjalani pekerjaannya sebagai body-guard di Copa Club. Masalah yang dialami oleh karakter Tony Lip diperkenalkan ketika ia harus mencari pekerjaan saat Copa Club tutup.

Dalam pola kejadian ini, karakter Tony Lip diperkenalkan sebagai seorang yang bekerja sebagai body guard di Copa Club. Selain itu, sifat sewenangwenang dan loyalitas Tony Lip juga diperkenalkan pada adegan awal ketika Tony memukul seorang pengunjung yang ricuh saat acara.

Pada akhir segment 1, masalah Tony Lip diperkenalkan pada saat Tony Lip menanyakan pekerjaan yang akan dilakukan oleh kedua teman kerjanya saat di depan Copa Club pada akhir adegannya. Hal tersebut menggambarkan masalah ekonomi yang dialami oleh karakter Tony Lip.
Dalam pola kejadian ini, Tony Lip digambarkan sebagai karakter yang pemberani. Hal tersebut ditunjukkan ketika ia memukul dan mengusir seseorang di Copa Club. Sifat sewenangwenangnya juga terlihat ketika ia mencuri topi Gio Loscudo.

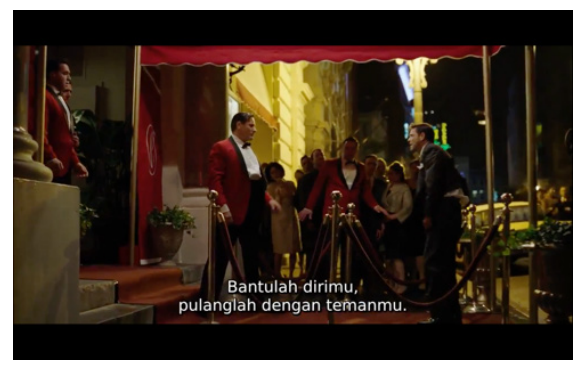

Gambar 1 Tony Lip bekerja sebagai body guard.

(Sumber: Potongan Film “Green Book”).

\section{Catalyst}

Catalyst dalam film "Green Book" terdapat pada plot segment 2 sampai 3. Dalam catalyst, karakter mulai mengalami dorongan untuk menyelesaikan masalahnya. Dalam film "Green Book", Tony Lip mulai mengalami dorongan mencari pekerjaan untuk keluarganya. Dalam plot segment 2a, Dolores meminta bantuan keluarga besarnya untuk membantu Tony Lip mencarikan pekerjaan, tetapi Tony Lip malu terhadap perlakuan Dolores. Dolores juga menceritakan bahwa Copa Club sedang direnovasi sehingga Tony Lip tidak dapat bekerja untuk sementara waktu. Ketika ada dua orang Negro datang, Tony Lip menghina dengan membuang kedua gelas di dapur. Pada plot segment $2 \mathrm{~b}$, Tony Lip juga mulai mencari cara untuk mendapatkan pekerjaan dengan cara mengikuti kontes makan. Hingga pada akhir plot segment $2 \mathrm{~b}$, Tony Lip mendapatkan tawaran dari Dr. Shirley dan menjalani wawancara untuk mencari pekerjaan. Sifat rasis Tony Lip terlihat ketika ia membuang dua gelas di dapur. Kesetiaan Tony Lip juga terlihat ketika ia mencoba untuk mengikuti kontes makan untuk kelaurganya. 


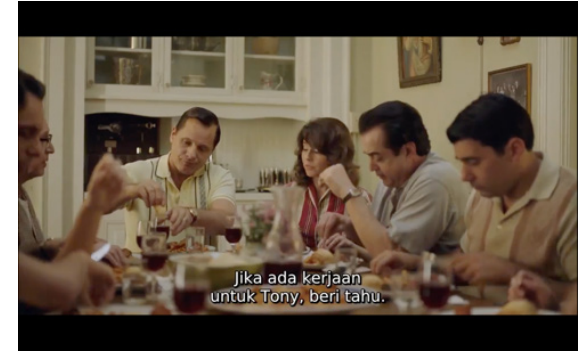

Gambar 2 Dolores memberitahu bahwa Tony Lip membutuhkan pekerjaan. (Sumber: Potongan Film

“Green Book”).

Pada plot segment 3a, Tony Lip melakukan wawancara di kantor Dr. Shirley. Sifat rasis Tony Lip muncul ketika ia bertemu dengan assistant India Dr. Shirley. Selain itu, sifat keras dan berani Tony Lip juga muncul ketika Tony menjalani wawancara dengan Dr. Shirley. Tony sempat menolak wawancara tersebut secara langsung. Sifat Dr. Shirley sebagai orang Negro yang berpendidikan juga diperkenalkan dengan sikap sopan santun dan gaya bicaranya kepada Tony Lip.

Pada plot segment 3b, Tony Lip mendapat tawaran dari teman-teman kerja lamanya, namun ia menolak. Keberanian Tony Lip terlihat ketika ia menolak untuk melakukan pekerjaan lamanya. Selain itu, pada plot segment 3c, Tony Lip juga menjual jam tangan untuk mendapatkan uang. Hingga pada plot segment 3d, Dr. Shirley memberitahukan bahwa Tony Lip mendapatkan pekerjaannya.

Pola kejadian Catalyst menunjukkan masalah eksternal karakter Tony Lip dalam mendapatkan uang untuk keluarganya. Dalam perjalanannya untuk mendapatkan keinginannya, sifat rasis Tony Lip terlihat ketika memperlakukan lingkungannya. Selain itu, sifat berani dan sewenang-wenang Tony Lip juga terlihat ketika ia menolak tawaran dari Dr. Shirley dan teman-teman lamanya.

\section{Big Event}

Big Event merupakan kejadian ketika karakter mulai melakukan perjalanan awalnya. Dalam film "Green Book", big event terdapat pada plot segment 4. Pada plot segment 4a, Tony Lip mendapat pekerjaan dari Dr. Sherley yang membawanya ke sebuah perjalanan bersama orang Negro. Tony menghadapi masalah ketika harus meninggalkan keluarganya selama dua bulan serta bertahan hidup bersama orang Negro. Namun ,Tony memilih untuk menjalani perjalanannya. Tony menenangkan keluarganya dan menjalani perjalanan bersama Dr. Shirley dan kedua temannya. Adegan pada plot segment 4 menggambarkan sifat ayah dari Tony Lip yang setia kepada keluarganya.

Pada plot segment 4a, Tony diperkenalkan dengan dengan tantangannya untuk mengantarkan Dr. Shirley tepat waktu serta membawa ke penginapan khusus orang Negro dengan buku petunjuk Green Book.

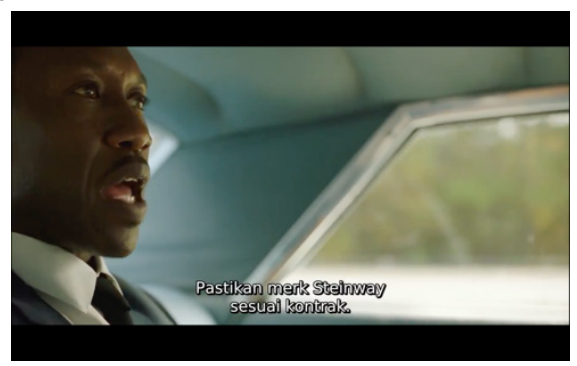

Gambar 3. Dr. Shirley memberi aturan pada Tony Lip.

(Sumber: Potongan Film “Green Book”).

Di plot segment ini, masalah luar (outer problem) dan masalah batin (inner problem) pada karakter Tony Lip mulai muncul. Outer problem karakter Tony Lip merupakan tujuannya untuk mengantarkan Dr. Shirley ke tujuan tepat waktu tanpa ada satu pun konser yang terlambat agar mendapatkan setengah gaji dari perjanjiannya serta pulang pada hari Natal. Sementara itu, inner problem dari karakter Tony Lip merupakan keinginannya untuk bertahan hidup bersama orang Negro, yaitu Dr. Shirley selama delapan minggu. Sifat rasis Tony Lip muncul saat Tony menyuruh assistant India Dr. Shirley untuk mengangkat barangnya.

Pada plot segment 4b, Tony Lip mulai mengalami masalah pertamanya karena Dr. Shirley menuntut Tony untuk fokus saat menyetir dan tidak merokok. Sifat rasis Tony masih terlihat ketika Tony menghina kedua teman Dr. Shirley dengan julukan orang Jerman. Tony juga menghina Dr. Shirley dengan mengambil dompetnya pada saat buang air kecil di jalan raya. 
Pada plot segment $4 \mathrm{c}$ Tony mulai berempati kepada Dr. Shirley. Tony juga mendapatkan masalah lain ketika ia harus menjaga perilaku dan gaya bicaranya saat di konser.

Pada plot segment $4 \mathrm{~d}$, Tony mendapatkan teguran lagi terhadap perilaku Tony saat Tony mengambil batu giok di tanah. Namun, Tony meresponsnya dengan mengalah walaupun sempat marah dan rasis.

Masalah eksternal Tony Lip terlihat ketika ia berusaha untuk menjalani pekerjaannya sebagai driver. Masalah internal terdapat pada sifat rasisnya kepada orang-orang yang baru dikenalnya. Di sepanjang perjalanannya, sifat rasis dari karakter Tony Lip terlihat ketika ia bertemu dengan orang India, Oleh, George, dan Dr. Sherley. Tony Lip juga bersifat sewenang-wenang ketika ia berbicara dengan Dr. Shirley dalam perjalanannya.

\section{Mid Point (Pinch)}

Mid point dalam film "Green Book" terdapat pada plot segment 5 dan 6. Mid point ditandai dengan perubahan sifat pada karakter Tony Lip yang tidak lagi rasis terhadap Dr. Shirley dan lingkungannya yang berbeda ras. Tony mulai melindungi Dr. Shirley dan dirinya sendiri dari kerasisan yang didalami.

Pada plot segment 5a, kesetiaan Tony Lip mulai muncul saat Tony menuntut grand piano bermerke Steinway dari seorang penjaga konser. Penjaga konser juga menghina Tony dengan menyebut greece ball atau orang Italia sehingga Tony harus memukul penjaga konser tersebut.

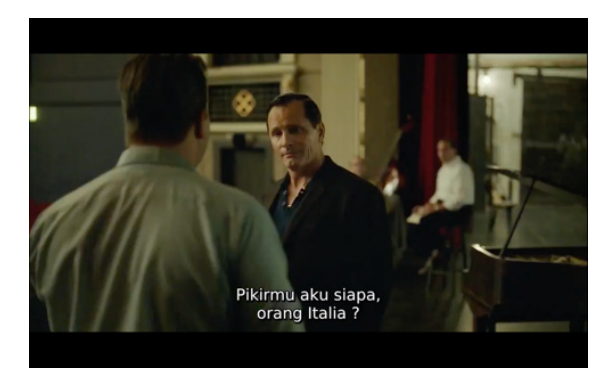

Gambar 4 Penjaga konser menghina Tony Lip.

(Sumber: Potongan Film "Green Book").
Pada plot segment 6a, Tony mulai memiliki hubungan dekat dengan Dr. Shirley yang ditandai dengan kejadian Dr. Shirley mulai menceritakan kisah hidupnya. Tony juga menawarkan ayam goreng yang membuat Dr. Shirley mulai nyaman. Tony tidak lagi rasis, tetapi Tony belajar untuk berbagi dengan orang yang berbeda ras.

Setelah itu, Tony Lip membantu mengangkat barang Dr. Shirley. Berbeda dengan plot segment 4a, yaitu Tony masih rasis dan menolak mengangkat barang Dr. Shirley. Tony juga mengalami masalah ketika Tony harus mengusir orang jahat yang menggangu Dr. Shirley saat mabuk di sebuah bar. Tony mulai menunjukkan gaya penyelesaian masalahnya dengan tawaran santai hingga keras untuk menyelesaikan masalahnya. Tony juga mulai peduli terhadap Dr. Shirley dengan menegur Dr. Shirley untuk pergi bersama Tony ke mana pun ia pergi. Pada akhir plot segment 6a, masalah internal karakter Dr. Shirley mulai terlihat ketika Dr. Shirley melihat petani Negro. Adegan tersebut menggambarkan refleksi kehidupan orang Negro sebagai kaum bawahan yang mengalami diskriminasi dari orang kulit putih yang ada di Amerika.

Pada plot segment 6b, Dr. Shirley mulai menghadapi masalah rasis terhadap orang kulit putih secara langsung, yaitu Dr. Shirley tidak boleh memakai toilet orang kulit putih dalam sebuah konser yang diadakan di Raleigh, North Carolina. Namun, Tony Lip mampu menyelesaikan masalah dengan mengantarkan Dr. Shirley ke motelnya. Tony Lip juga mendapatkan ancaman dari salah satu teman Dr. Shirley untuk membiarkan Dr. Shirley mengalah kepada kulit putih saat menghadapi diskriminasi. Namun, Tony Lip memilih untuk tetap membela Dr. Shirley atas diskriminasi yang dialami. Sepanjang perjalanan dari Raleigh hingga ke daerah Macon, Georgia, hubungan Tony Lip dan Dr. Shirley semakin dekat. Selain itu, Dr. Shirley mengajari Tony Lip untuk menulis surat untuk keluarganya. 
Pada plot segment 6c, masalah yang dialami tidak lagi berpusat pada Tony Lip, tetapi pada Dr. Shirley. Di sebuah toko pakaian, Dr. Shirley terus mengalami diskrimininasi tidak diperbolehkan mencoba toxedo yang disukainya. Namun, Dr. Shirley melawan dengan keluar dari toko tersebut. Selain itu, di akhir segment $6 \mathrm{c}$, Tony Lip juga mengalami masalah karena Tony harus membebaskan Dr. Shirley dari penangkapan yang dilakukan oleh polisi. Namun, Tony Lip mampu menghadapinya dengan cara menyuap polisi tersebut.

Pada plot segment 7a sampai 7c, Tony Lip menunjukkan sifat terbukanya ketika Dr. Shirley mencoba membantu menulis surat untuk keluarganya. Kedekatannya dengan Dr. Shirley juga terlihat ketika mereka bercanda selama perjalanannya.

Pada plot segment 7d, Dr. Shirley mengalami diskriminasi dari kedua teman Tony Lip karena Tony Lip ditawari pekerjaan dengan gaji dua kali lipat daripada yang diberikan Dr. Shirley dengan bahasa Itali. Namun, Dr. Shirley membalasnya dengan menawari Tony Lip sebagai assistant manager-nya dengan kenaikan gaji. Kesetiaan Tony Lip terlihat saat Tony Lip memilih untuk tetap menjalani perjanjiannya kepada Dr. Shirley.

Masalah eksternal karakter Tony Lip terlihat ketika ia berusaha untuk menjalankan pekerjaannya dengan baik. Sementara itu, masalah internal karakter Tony Lip tidak lagi terletak pada sifat rasisnya, tetapi pada kepeduliannya terhadap Dr. Shirley. Di sepanjang perjalanannya dalam mengatasi masalah tersebut, sifat berani dan sewenang- wenang karakter Tony Lip terlihat ketika ia berusaha untuk melindungi Dr. Shirley dari berbagai ancaman kerasisan yang terjadi di lingkungannya.

\section{Crisis}

Crisis dalam film "Green Book" terdapat pada plot segment 8a. Keloyalitasan Tony Lip diuji saat polisi rasis terhadap Dr. Shirley. Tony mengalami diskriminasi ketika seorang polisi menyebutnya dengan kata "setengah Negro" yang menyebabkan Tony memukul polisi tersebut. Masalah diskriminasi ras dari lingkungan di Louisiana semakin besar.

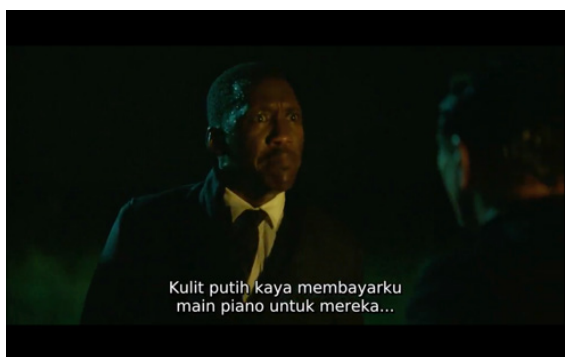

Gambar 5 Titik terendah cerita ketika Dr. Shirley mengakui luka batinnya sebagai orang Negro. (Sumber: Potongan Film "Green Book").

Tony Lip juga mengalami masalah karena ia dan Dr. Shirley harus dipenjara. Titik terendah terjadi saat Tony dan Dr. Shirley saling berdebat tentang diskriminasi yang mereka alami. Masalah batin karakter memuncak saat Dr. Shirley menceritakan kehidupan lamanya tentang diskriminasi sebagai orang Negro yang hanya mencari "uang" demi martabatnya.

Masalah internal Tony Lip terlihat ketika ia mencoba untuk memahami dan peduli kepada Dr. Shirley. Sementara itu, masalah eksternal karakter Tony Lip muncul ketika ia dipenjara dan harus melanjutkan perjalanannya. Keberanian dan sifat sewenang-wenang Tony Lip muncul ketika ia mencoba memukul polisi yang menghina rasnya.

\section{Showdown atau Climax}

Showdown atau Climax dalam film "Green Book" terjadi pada plot segment 8b ketika Dr. Shirley dihadapkan pada pilihan yang berat antara mempertahankan martabatnya sebagai orang Negro atau mendapatkan uang tiga kali lipat dari konser terakhirnya. Adegan tersebut terjadi saat Dr. Shirley tidak diperbolehkan makan di restoran bersama orang kulit putih. Tony Lip melindungi Dr. Shirley dengan gaya tawar-menawarnya. Namun, Dr. Shirley memilih untuk mempertahankan martabatnya dan keluar dari restoran bersama Tony Lip. 
Masalah eksternal yang dialami oleh karakter Tony Lip adalah pekerjaannya. Ia dihadapkan dengan tantangan terakhir untuk menyelesaikan kontrak pekerjaannya. Namun, di sisi lain, Tony Lip memiliki masalah internal, yaitu martabat yang dipertahankan sebagai manusia. Sifat sewenangwenang Tony Lip terlihat ketika ia berusaha untuk memaksa penjaga restoran agar Dr. Shirley dapat makan di restoran tersebut. Tony Lip juga memiliki keberanian untuk melawan aturan karena ia membela Dr. Shirley daripada kontrak kerjanya.

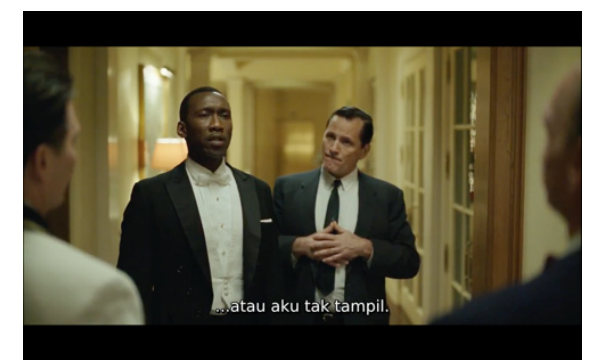

Gambar 6 Dr. Shirley memilih untuk mempertahankan martabatnya (Sumber: Potongan Film "Green Book").

Pada akhir plot segment 8b, Dr. Shirley dan Tony berkunjung di sebuah bar orang Negro. Di bar tersebut, Dr. Shirley menunjukkan kemampuannya dengan menggunakan piano tanpa merek di depan orang Negro kelas menengah ke bawah. Adegan tersebut melambangkan martabatnya sebagai orang Negro yang dipertahankannya. Berbeda dengan pola kejadian Back Story saat Tony Lip tidak terbuka terhadap sekelilingnya yang berbeda warna kulit. Dalam adegan tersebut, Tony Lip memberi dukungan kepada Dr. Shirley. Kesetiaan Tony Lip juga terlihat ketika ia melindungi Dr. Shirley dari penjahat yang bersembunyi di balik mobilnya. Dari tindakannya, Tony Lip tidak lagi menjadi karakter yang bersifat rasis. Ia juga belajar untuk memedulikan orang yang berbeda ras dari ras yang dimilikinya.

\section{Realization}

Realization dalam film "Green Book" terdapat pada plot segment 9. Pada plot segment 9a, seorang polisi membantu Tony Lip dan Dr. Shirley untuk memperbaiki mobilnya tanpa diskriminasi. Mereka saling menyapa dan memberi salam Natal.

Kejadian tersebut sangat kontras dengan polisi pada plot segment 8a yang menggambarkan polisi yang rasis. Ditutup dengan plot segment $9 \mathrm{~b}$ saat Tony Lip dan Dr. Shirley berhasil menyelesaikan perjalanan mereka dan kembali ke rumah mereka masing-masing. Perubahan karakter terlihat pada saat Tony Lip merayakan Natal bersama keluarga besarnya.

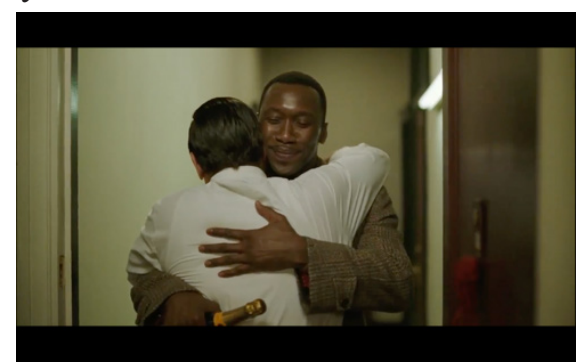

Gambar 7 Perubahan sifat Tony Lip dari rasis menjadi tidak rasis (Sumber: Potongan Film “Green Book”).

Pada saat Tony Lip menyambut tamu, Dr. Shirley berkunjung ke rumahnya. Berbeda dengan adegan sebelumnya, Tony Lip memeluk Dr. Shirley dengan penuh kehangatan. Selain itu, Dolores juga memberikan sambutan kepada Dr. Shirley karena sudah memberi pekerjaan kepada Tony. Seluruh keluarga Tony mempersilahkan Dr. Shirley untuk makan bersama. Pesan dan tema dalam film "Green Book" ditonjolkan sepanjang cerita bahwa persahabatan tidak melihat warna kulit, tetapi saling mendukung dalam menjalani sebuah perjalanan. Kejadian terakhir tersebut menggambarkan sifat keterbukaan karakter Tony Lip terhadap orang dengan ras lain.

\section{Perubahan Karakter Tony Lip}

Perubahan sifat karakter Tony Lip di sepanjang perjalanan yang dihadapi terletak pada sifat diskriminasi terhadap orang Negro yang ada di lingkungannya. Pada pola kejadian Back Story, Catalyst, dan Big Event, Tony Lips melakukan diskriminasi terhadap Dr. Shirley, assistant India Dr. Shirley, kedua teman Jerman Dr. Shirley. Namun, pada pola kejadian mid point (pinch), crisis, showdow (climax), dan realization, Tony 
Lip tidak lagi rasis terhadap Dr. Shirley dan orang di sekitarnya. Tony memilih untuk melindungi Dr. Shirley dari diskriminasi yang dialami dari orang kulit putih, akibatnya Tony Lip juga mengalami diskriminasi. Selain itu, Tony Lip tetap memiliki sifat berani dan sewenang- wenangnya hingga akhir cerita.

\section{SIMPULAN}

Berdasarkan penelitian yang dilakukan, disimpulkan bahwa terdapat 7 pola kejadian yang dapat digambarkan melalui 9 plot segment di sepanjang perjalanan karakter dalam sebuah cerita film. Pola kejadian tersebut juga menggambarkan masalah-masalah dari luar (outer problem) dan masalah-masalah dari dalam (inner problem) yang dialami tokoh utama dalam sebuah cerita. Melalui pola kejadian tersebut, perubahan sifat karakter Tony Lip terjadi sepanjang perjalanan yang dihadapi. Perubahan karakter tersebut memberi nilai yang merefleksikasn nilai-nilai kehidupan.

\section{KEPUSTAKAAN}

Bordwell, D., \& Thompson, K. (2019). Film Art: An Introduction. In Style DeKalb IL. https:// doi.org/film;cultural studies;semiotik

Egri, L. (1946). The art of dramatic writing. In The Art Book. https://doi.org/10.1111/j.14678357.2006.00681_2.x

Farrelly, P. (2019). Green Book. In Cineforum (Vol. 59, Issue 2, pp. 26-28). https://doi. org/10.1093/jahist/jaz666

Oktaviani, D. D. (2019). "Konsep Fantasi dalam Film.” REKAM: Jurnal Fotografi, Televisi, Animasi, 15, No. 2, 125-136.

Sari, R. J. (2020). Analisis peran perubahan karakter tokoh utama dalam pembangunan tahapan tangga dramatik pada Film SPLIT. Rekam, 16(2), 87-102. https://doi. org/10.24821/rekam.v16i2.4244
Snyder, B. (2005). Save The Cat! The Last Book on Screenwriting You'll Ever Need. http://www. amazon.com/Save-Last-Book-ScreenwritingYoull/dp/1932907009

Trottier, D. (2019). Dialogue. Proper formatting technique - a style guide. In The screenwriter's bible : a complete guide to writing, formatting, and selling your script.

Vogler, C. (2007). The writer's journey : mythic structure for writers. Michael Wiese Productions; 3rd Edition (November 1, 2007). https://www.amazon.com/Writers-JourneyMythic-Structure-3rd/dp/193290736X 